\title{
Temperature-dependent Azide Sensitivity of Growth and ATPase Activity in the Facultative Thermophile, Bacillus coagulans
}

\author{
By M. V. JONES*, W. N. SPENCER AND C. EDWARDS \\ Department of Microbiology, Life Sciences Building, University of Liverpool, P.O. Box 147, \\ Liverpool L69 3BX, UK
}

(Received 25 July 1983; revised 4 October 1983)

\begin{abstract}
Inhibition by sodium azide of the growth of Bacillus coagulans decreased but the cytochrome content, particularly cytochrome $d$, increased with increasing growth temperature. Higher cytochrome $d$ content correlated with increased cyanide resistance of NADH oxidase, but azide resistant activity was found in mesophilic and thermophilic cultures. Anaerobic growth at $37^{\circ} \mathrm{C}$ was totally inhibited by $1 \mathrm{~mm}$-azide. At $55^{\circ} \mathrm{C}$ growth occurred with $4 \mathrm{~mm}$-azide, but the cell yield was reduced by $60 \%$. ATPase activity was sensitive to azide but inhibition varied with both growth and assay temperatures. ATPase from cells grown at $55^{\circ} \mathrm{C}$ was least sensitive when assayed at $55^{\circ} \mathrm{C}$. Possible changes in ATPase which could account for the temperaturedependent azide sensitivity are discussed.
\end{abstract}

\section{INTRODUCTION}

Facultative thermophiles are capable of growth in both the thermophilic and mesophilic temperature ranges (Farrell \& Campbell, 1969). Several reports have suggested that unlike obligate thermophiles, in which the majority of proteins are intrinsically thermostable (Williams, 1975), facultative thermophiles may contain thermolabile enzymes which require modification or stabilization to operate at high growth temperatures. Recently, studies on several enzymes from Bacillus flavothermus and a facultatively thermophilic Streptomyces sp. resulted in the conclusion that 'a facultatively thermophilic organism can harbour two types of enzyme, namely those with increasing thermostability depending on growth temperature and those which remain thermolabile' (Heinen \& Lauwers, 1983). Earlier, the glyceraldehyde phosphate dehydrogenase of Bacillus coagulans $\mathrm{KU}$ was shown to be very labile, even from cells grown at $55^{\circ} \mathrm{C}$, unless stabilized by high ionic strength (Crabb et al., 1975). This led to a generalized theory of facultative thermophily which proposed that the enzymes of such organisms were not intrinsically thermostable (Crabb et al., 1975; Amelunxen \& Murdock, 1978). However, recently the ATPase of $B$. coagulans has been shown to be thermostable (Edwards \& Jones, 1983). More work is therefore needed to establish if facultative thermophiles do possess particular and possibly unique mechanisms which allow growth at thermophilic temperatures. The increasing use of microbial enzymes (especially from Bacillus sp.) for biotechnological purposes makes studies of intrinsic and conferred thermostability of considerable interest.

Bacillus coagulans was chosen for the present study because of its wide temperature range (Gordon et al., 1973) and because growth rates alter little between mesophilic $\left(37^{\circ} \mathrm{C}\right)$ and thermophilic $\left(55^{\circ} \mathrm{C}\right)$ conditions (Novitsky et al., 1974; Amelunxen \& Murdock, 1978). Bacillus coagulans can be readily distinguished from other bacilli growing at $55^{\circ} \mathrm{C}$ or above by its tolerance to sodium azide and the production of lactic acid as the major fermentation product (Gordon et al., 1973; Gibson \& Gordon, 1974). The insensitivity to azide may reflect differences in terminal respiratory oxidases or a shift to fermentative growth. This report examines the effects of both temperature and sodium azide on the energy-yielding metabolism of $B$. coagulans. 


\section{METHODS}

Organism and growth conditions. Bacillus coagulans (NCIB 8080) was grown aerobically in tryptone/yeastextract/glucose (TYG) broth in conical flasks as previously described (Edwards \& Jones, 1983) or in a 101 batch fermenter (L. H. Engineering Co. Ltd, Stoke Poges, Bucks, UK) containing 71 broth aerated at 71 air $\mathrm{min}^{-1}$ and stirred at 300 r.p.m. Sterile antifoam agent (Silicone Antifoam Emulsion A, Sigma) was added as required. The fermenter was inoculated with a $5 \%(\mathrm{v} / \mathrm{v})$ overnight aerobic culture.

Anaerobic growth was in tubes containing $10 \mathrm{ml}$ TYG broth which had been autoclaved and cooled to the growth temperature prior to inoculation with $0.05 \mathrm{ml}$ overnight anaerobic culture. Tubes were incubated in an anaerobic jar (GasPak, BBL).

Growth was monitored at $550 \mathrm{~nm}$ and converted to dry weight using a calibration curve prepared using cells grown in TYG.

Preparation of cell extracts. Cell extracts for ATPase assays were prepared as described previously (Edwards \& Jones, 1983). For other assays, samples ( 1 litre) of fermenter culture were harvested by centrifugation at $15000 \mathrm{~g}$ for $10 \mathrm{~min}$ at $4{ }^{\circ} \mathrm{C}$, washed once in cold $50 \mathrm{~mm}$-potassium phosphate buffer (pH 7.4) containing $5 \mathrm{mM}-\mathrm{MgCl}_{2}$ and resuspended in the same buffer. Cells were disrupted by sonication for a total of 2-3 min using a MSE Ultrasonic Disintegrator (MSE Ltd, Crawley, UK) at an amplitude setting of $12 \mu \mathrm{m}$ peak to peak. Cell breakage was assessed using phase-contrast microscopy. Whole cells were removed by centrifugation at $10000 \mathrm{~g}$ for $10 \mathrm{~min}$ and the supernatant, containing 4-10 $\mathrm{mg}$ protein $\mathrm{ml}^{-1}$ used as the cell extract. Membrane fraction was prepared by lysozyme treatment as described by McArthur \& Reynolds (1979).

ATPase assays. ATPase was assayed by a proton-release method essentially as described previously by West $\&$ Mitchell (1974) and Edwards et al. (1978). Cell extracts (0.5-1 mg protein) were added to ATPase buffer (total assay volume $3 \mathrm{ml}$ ) which contained $0 \cdot 15 \mathrm{M}-\mathrm{KCl}, 28 \mathrm{mM}$-glycyl-glycine and $1 \mathrm{mM}-\mathrm{MgCl}_{2}$ (pH 8). After temperature equilibration and addition of azide, the $\mathrm{pH}$ was adjusted to $\mathrm{pH} 8$ with either $50 \mathrm{~mm}-\mathrm{KOH}$ or $50 \mathrm{~mm}$ $\mathrm{HCl}$. The reaction was initiated by the addition of $50 \mu \mathrm{l} 0.1 \mathrm{M}-\mathrm{ATP}, \mathrm{pH} \mathrm{8.0.} \mathrm{The} \mathrm{progressive} \mathrm{decrease} \mathrm{in} \mathrm{pH}$ resulting from ATP hydrolysis was monitored using a long-reach pH micro electrode (Russell pH Ltd, Fife, UK) linked via an EIL $7030 \mathrm{pH}$ meter (EIL, Chertsey, Surrey, UK) to a Vitatron chart recorder (MSE, Crawley, Sussex, UK). No ATP hydrolysis occurred with buffer alone. ATPase activity was determined from the initial rate of hydrolysis (1-2 min). The mixture was calibrated by the addition of $5 \mu \mathrm{l} 0.05 \mathrm{M}-\mathrm{HCl}$ on the basis that hydrolysis of one molecule of ATP releases 1.0 proton at $\mathrm{pH} 8.0$ (Alberty, 1968).

Cytochrome content. Difference spectra of cell extracts or membrane fractions were plotted using a SP1800 spectrophotometer (Pye Unicam, Cambridge, UK). Samples were reduced by the addition of solid sodium dithionite and oxidized either by vigorously shaking in air or by the addition of solid potassium ferricyanide. COReactive components were identified from reduced plus $\mathrm{CO}$ minus reduced difference spectra. $\mathrm{CO}$ gas was bubbled through dithionite reduced membrane fraction for between 1 and $10 \mathrm{~min}$. Cytochrome concentrations were calculated using extinction coefficients given by Smith (1978).

Other assays. NADH oxidase was measured spectrophotometrically at $340 \mathrm{~nm}$. The reaction mix contained (final volume, $1 \mathrm{ml}$ ): $50 \mu \mathrm{mol}$ potassium phosphate buffer $(\mathrm{pH} 7 \cdot 4), 5 \mu \mathrm{mol} \mathrm{MgCl}_{2}$ and cell extract $(50-200 \mu \mathrm{g}$ protein). The reaction was started by the addition of NADH $(2 \mu \mathrm{mol})$. Inhibitors $\left(\mathrm{NaN}_{3}\right.$ or KCN) were added before the substrate.

Protein was determined by the Lowry method using bovine serum albumin as the standard.

\section{RESULTS}

Aerobic growth in the presence of azide

Growth at $55^{\circ} \mathrm{C}$ in the presence of sodium azide is used as a diagnostic test for Bacillus coagulans (Gordon et al., 1973). This resistance was not found at lower incubation temperatures. At $55^{\circ} \mathrm{C}$ aerobic growth in broth containing $1 \mathrm{~mm}$-azide was only slightly slower (doubling time $58 \mathrm{~min}$ ) than in the absence of the inhibitor (doubling time $42 \mathrm{~min}$ ), but the final yield of cells was decreased (Fig. 1). With 2 mm-azide the cell yield was reduced by $75 \%$. If the growth temperature was reduced, inhibition by azide became progressively more severe so that at $45^{\circ} \mathrm{C}$ (doubling time $45 \mathrm{~min}$ in absence of azide) no growth was detected in broth containing $2 \mathrm{~mm}$ azide (Fig. 1). Preincubation of medium containing azide for $18 \mathrm{~h}$ at $55^{\text {" }} \mathrm{C}$ before cooling and inoculation at lower temperatures indicated that the differences in growth inhibition were not due to instability of azide at $55^{\circ} \mathrm{C}$. 

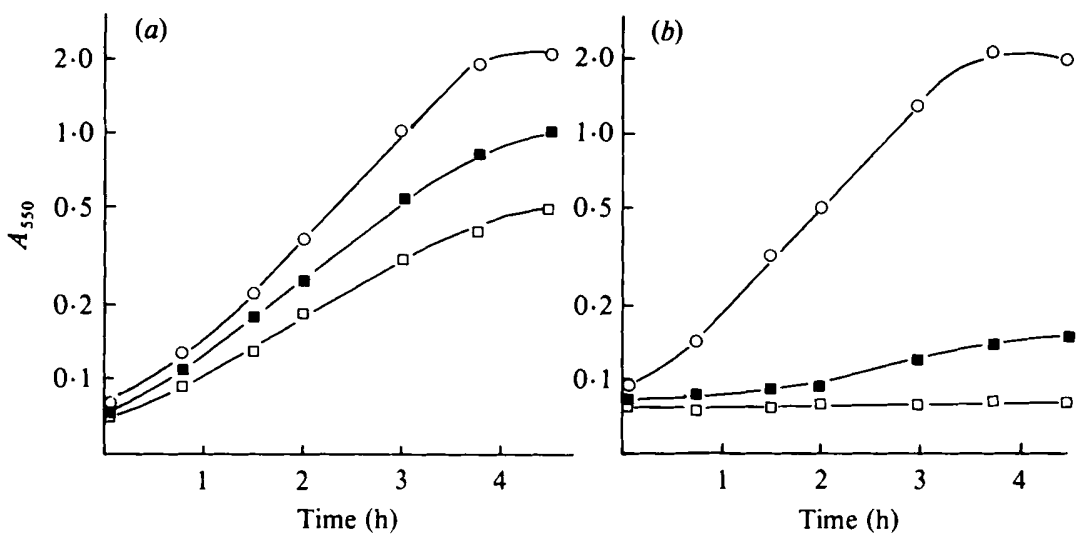

Fig. 1. Effect of sodium azide on the growth of Bacillus coagulans. Growth at $(a) 55^{\circ} \mathrm{C}$ or $(b) 45{ }^{\circ} \mathrm{C}$ was measured in the absence $(O)$ or presence of $1 \mathrm{~mm}-(\square)$ and $2 \mathrm{mM}^{-}(\square)$ sodium azide.

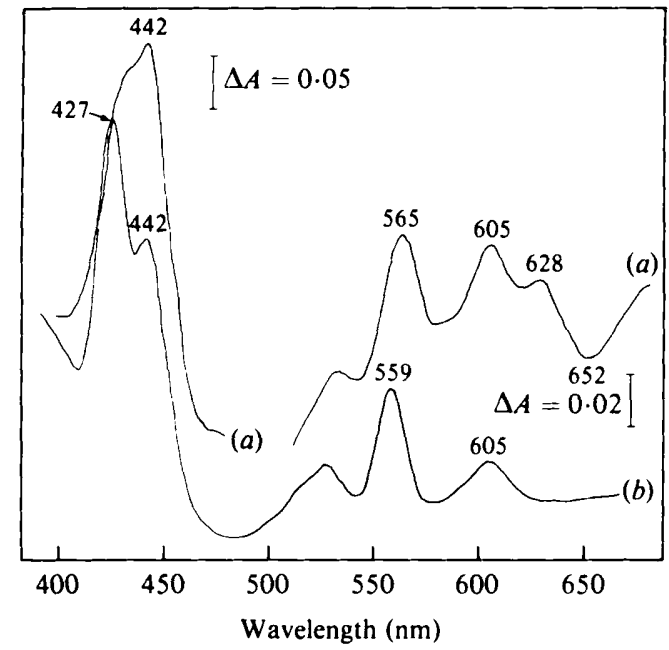

Fig. 2. Room temperature difference spectra of membrane fractions. Reduced (dithionite) minus oxidized (air) difference spectra were plotted of membrane fractions prepared from late-exponential phase cultures grown at $(a) 55^{\prime \prime} \mathrm{C}$ or $(h) .35^{\circ} \mathrm{C}$. Protein concentrations were $(a) 19.8 \mathrm{mg} \mathrm{ml}^{-1}$ and $(h)$ $10 \cdot 1 \mathrm{mg} \mathrm{ml}$ '.

\section{Effect of temperature on respiratory chain composition}

To investigate whether the azide resistance at high temperatures was attributable to changes in the respiratory chain, the cytochrome composition of $B$. coagulans grown at various temperatures was measured. Both quantitative and qualitative differences were apparent between organisms grown at $55^{\circ} \mathrm{C}$ and $35^{\circ} \mathrm{C}$. The cytochromes in reduced minus oxidized spectra of membrane fractions prepared from $55^{\circ} \mathrm{C}$-grown cultures were cytochrome $b\left(\alpha_{\max }\right.$ $565 \mathrm{~nm})$, cytochrome $a a_{3}\left(\alpha_{\max } 605 \mathrm{~nm}\right)$ and cytochrome $d\left(\alpha_{\max } 628 \mathrm{~nm}\right)$. No cytochrome $c$ was detected (Fig. 2a). The presence of two terminal oxidases was also indicated in a reduced plus $\mathrm{CO}$ minus reduced spectrum. This did not show the presence of cytochrome $o$ even after prolonged exposure to $\mathrm{CO}$. In membrane fractions from a $35^{\circ} \mathrm{C}$-grown culture only cytochromes $a a_{3}$ and $b$ were observed (Fig. $2 b$ ). The maximum of cytochrome $b$ in $35^{\circ} \mathrm{C}$ grown cells was $559 \mathrm{~nm}$. The reduced plus $\mathrm{CO}$ minus reduced spectrum also indicated that only one oxidase (cytochrome $a a_{3}$ ) was present.

When the growth temperature was increased from $35^{\circ} \mathrm{C}$ to $40^{\circ} \mathrm{C}$, slight traces of cytochrome $d$ were sometimes observed in stationary phase but not in exponentially-growing cultures. A 
Table 1. Effects of growth temperature on cytochrome composition and NADH oxidase activity in Bacillus coagulans

\begin{tabular}{|c|c|c|c|c|c|c|}
\hline \multirow[b]{2}{*}{$\begin{array}{l}\text { Growth } \\
\text { temperature }\end{array}$} & \multirow[b]{2}{*}{ Growth phase } & \multicolumn{3}{|c|}{ [nmol (mg protein) $\left.{ }^{-1}\right]$} & \multirow{2}{*}{$\overbrace{\begin{array}{c}\text { Specific } \\
\text { activity* }\end{array}}$} & \multirow[b]{2}{*}{$\begin{array}{c}\text { Inhibition } \\
5 \mathrm{~mm}-\mathrm{KCN}(\%)\end{array}$} \\
\hline & & $\overbrace{a a_{3}}$ & $b$ & $d$ & & \\
\hline $55^{\circ} \mathrm{C}$ & $\begin{array}{l}\text { Early-exponential } \\
\text { Late-exponential } \\
\text { Stationary }\end{array}$ & $\begin{array}{l}0 \cdot 109 \\
0 \cdot 205 \\
0 \cdot 402\end{array}$ & $\begin{array}{l}0.233 \\
0.461 \\
0.838\end{array}$ & $\begin{array}{l}0 \cdot 053 \\
0 \cdot 436 \\
0 \cdot 829\end{array}$ & $\begin{array}{l}0 \cdot 106 \\
0.042 \\
0.039\end{array}$ & $\begin{array}{l}81 \\
68 \\
45\end{array}$ \\
\hline $40^{\circ} \mathrm{C}$ & $\begin{array}{l}\text { Early-exponential } \\
\text { Late-exponential } \\
\text { Stationary }\end{array}$ & $\begin{array}{l}0.021 \\
0.054 \\
0.053\end{array}$ & $\begin{array}{l}0.114 \\
0.148 \\
0.117\end{array}$ & $\begin{array}{l}0 \\
0 \\
0 \cdot 031\end{array}$ & $\begin{array}{l}0.072 \\
0.053 \\
0.036\end{array}$ & $\begin{array}{l}83 \\
77 \\
71\end{array}$ \\
\hline
\end{tabular}

more detailed examination of cytochrome composition during growth at $40{ }^{\circ} \mathrm{C}$ and $55^{\circ} \mathrm{C}$ is presented in Table 1 . The cytochrome content was always higher at the higher growth temperature and at $55^{\circ} \mathrm{C}$ substantial increases in all three cytochromes (but particularly cytochrome $d$ ) occurred as stationary phase was reached. At $40^{\circ} \mathrm{C}$ some increase in the amount of cytochrome $a a_{3}$ in stationary phase cells was measured, but the level was eight fold lower than at $55^{\circ} \mathrm{C}$.

Increased cytochrome $d$ content was accompanied by increased resistance of respiration to cyanide. NADH oxidase activity was only slightly higher in organisms grown at $55^{\circ} \mathrm{C}$ compared with $40{ }^{\circ} \mathrm{C}$ but up to $55 \%$ of the activity was resistant to $5 \mathrm{~mm}-\mathrm{KCN}$ (Table 1 ).

It seemed possible that the increased azide resistance at $55^{\circ} \mathrm{C}$ compared to $45^{\circ} \mathrm{C}$ or below was due, in part, to the presence of an additional cytochrome oxidase, cytochrome $d$. However, NADH oxidase activity, measured either spectrophotometrically or with an oxygen electrode, was very resistant to azide, irrespective of the growth temperature. With $10 \mathrm{~mm}$-azide the inhibition of NADH oxidase was only $16 \%$ and $21 \%$ in membrane fractions prepared from cultures grown at $55^{\circ} \mathrm{C}$ and $35^{\circ} \mathrm{C}$, respectively. Furthermore, the addition of azide to cultures growing at a variety of temperatures did not induce additional synthesis of cytochrome $d$ or change the cytochrome composition.

The presence of cytochrome $d$ in cultures grown at $55^{\circ} \mathrm{C}$ could also reflect a greater thermostability of this oxidase compared with cytochrome $a a_{3}$. Measurement of NADH oxidase activity remaining after heating cell-extracts for $5 \mathrm{~min}$ at temperatures up to $75^{\circ} \mathrm{C}$ showed that there was little difference in cells grown at $55^{\circ} \mathrm{C}$ or $35^{\circ} \mathrm{C}$. In both, the enzyme was stable up to $60^{\circ} \mathrm{C}$. Above this temperature it was rapidly inactivated so that after heating at $70^{\circ} \mathrm{C}$, no enzyme activity could be detected.

\section{Anaerobic growth in the presence of azide}

Growth under anaerobic conditions was examined to determine whether azide affected respiration and fermentative metabolism equally. At $55^{\circ} \mathrm{C}$ anaerobic growth was possible even in the presence of $4 \mathrm{~mm}$-azide although the cell-yield was reduced at all inhibitor concentrations (Table 2). The final $\mathrm{pH}$ of all the cultures was approximately $4 \cdot 1$. Increasing the medium glucose concentration did not change the final $\mathrm{pH}$ but instead resulted in unmetabolized glucose being present in the culture supernatant. Lactic acid was the main product detected in the culture supernatants and the amount formed was not altered by the presence of azide (data not shown). At lower temperatures, anaerobic growth like aerobic growth became more and more sensitive to azide. At $37^{\circ} \mathrm{C}$ growth was completely inhibited by $2 \mathrm{~mm}$-azide (Table 2). In the absence of azide, cell yields and acid production were similar at both growth temperatures (Table 2 ).

\section{Effect of azide on ATPase}

The fact that both aerobic and anaerobic growth in the presence of azide resulted in reduced cell yields prompted experiments to investigate the effect of azide on the ATPase of B. coagulans. 
Table 2. Anaerobic growth in the presence of sodium azide

Bacillus coagulans was grown anaerobically at $55^{\circ} \mathrm{C}$ or $37^{\circ} \mathrm{C}$ in TYG broth with or without sodium azide. Culture $\mathrm{pH}$ and cell yield were determined after $18 \mathrm{~h}$ growth. Initial $\mathrm{pH}=6 \cdot 2$.

$\begin{array}{lcccc}\begin{array}{c}\text { Azide } \\ (\mathrm{mm})\end{array} & \overbrace{\begin{array}{c}\text { Dry wt } \\ \left(\mathrm{mg} \mathrm{ml}^{-1}\right)\end{array}}^{5{ }^{\circ} \mathrm{C}} & \overbrace{\begin{array}{c}\text { Dry wt } \\ \left(\mathrm{mg} \mathrm{m}^{-1}\right)\end{array}}^{37^{\circ} \mathrm{C}} & \mathrm{pH} \\ 0 & 0.26 & 4.10 & 0.27 & 4.20 \\ 0.5 & 0.20 & 4.05 & 0.13 & 4.45 \\ 1 & 0.18 & 4.03 & 0.06 & 4.90 \\ 2 & 0.14 & 4.03 & 0 & 5.95 \\ 4 & 0.10 & 4.10 & 0 & 6.20\end{array}$

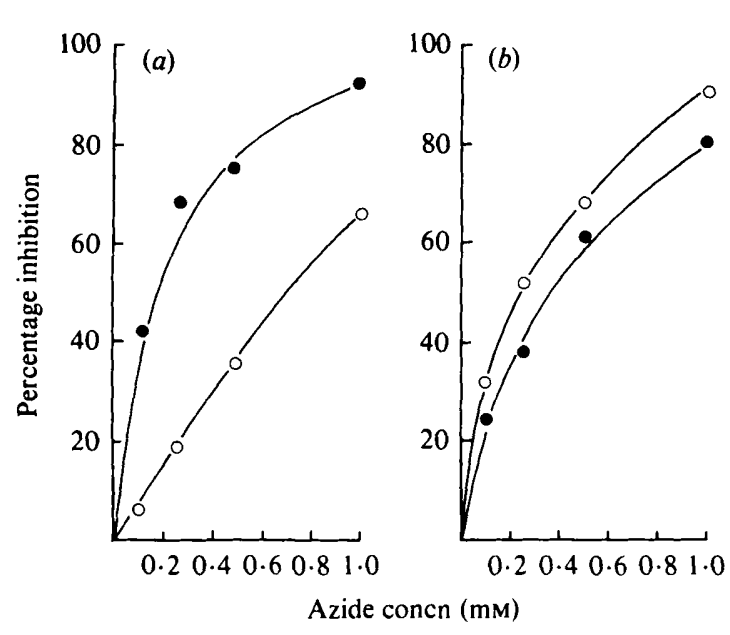

Fig. 3

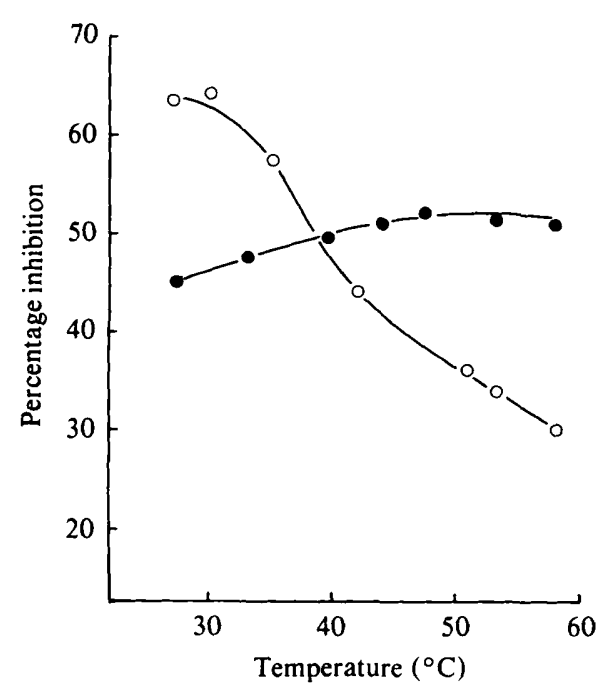

Fig. 4

Fig. 3. Inhibition by azide of ATPase activity. Cell-free extracts prepared from cells grown at $(a) 55^{\circ} \mathrm{C}$ or $(b) 37^{\circ} \mathrm{C}$ were assayed at $55^{\circ} \mathrm{C}(\mathrm{O})$ or $37^{\circ} \mathrm{C}(\mathrm{O})$ in the presence of 0 to $1 \mathrm{mM}$-sodium azide and percentage inhibition was calculated.

Fig. 4. Effect of assay temperature on azide inhibition of ATPase activity. Cell extracts from ceils grown at $55^{\circ} \mathrm{C}(\mathrm{O})$ or $37^{\circ} \mathrm{C}(\mathrm{O})$ were assayed in the presence and absence of $0.3 \mathrm{~mm}$-sodium azide and the percentage inhibition was calculated.

When assayed at mesophilic temperatures (e.g. $37^{\circ} \mathrm{C}$ ), the ATPase from cells grown at $37^{\circ} \mathrm{C}$ was inhibited slightly less by azide (0.1-1 mM) than cells grown at $55^{\circ} \mathrm{C}$ (Fig. 3). In contrast, when assayed at $55^{\circ} \mathrm{C}$ ATPase activity in cells grown at $55^{\circ} \mathrm{C}$ was much less sensitive, whereas ATPase from $37^{\circ} \mathrm{C}$-grown cells was slightly more sensitive (Fig. 3). The sensitivity to azide therefore depends both on the growth and assay temperature. To confirm this, the activity in the presence of a fixed concentration of azide $(0.3 \mathrm{~mm})$ was determined over the whole growth temperature range $\left(27-58^{\circ} \mathrm{C}\right)$ for both $55^{\circ} \mathrm{C}$ - and $37^{\circ} \mathrm{C}$-grown culture. The results (Fig. 4) show that for $55^{\circ} \mathrm{C}$-grown cells the ATPase became progressively less sensitive to azide as the temperature of the assay was increased, while for $37^{\circ} \mathrm{C}$-grown cells the reverse trend was seen. However, the effect of temperature on the azide sensitivity of ATPase from $37^{\circ} \mathrm{C}$-grown cells was much less pronounced.

\section{DISCUSSION}

It was unexpected that growth of Bacillus coagulans should become more sensitive to azide as the incubation temperature was lowered. This suggested that some major change in metabolism was occurring during the transition from thermophilic to mesophilic conditions. In view of the 
known effects of azide as the respiratory poison and the previous work on thermoadaptation of Bacillus stearothermophilus (Jung et al., 1974), where fermentation and respiration are active at $55^{\circ} \mathrm{C}$ but only respiration at $37^{\circ} \mathrm{C}$, it was anticipated that azide would be found to inhibit respiration in $B$. coagulans at least under mesophilic conditions.

A study of the cytochrome composition of $B$. coagulans grown at different temperatures revealed both quantitative and qualitative differences. The large amount of cytochrome $d$ present in cells grown at $55^{\circ} \mathrm{C}$ and especially in stationary-phase cultures is probably a reflection of lower oxygen solubility and therefore availability in dense cultures. Cytochrome $d$ has been found in other bacteria under conditions of oxygen limitation (Rice \& Hempfling, 1978) or in stationary phase cultures (Castor \& Chance, 1959). However, attempts to induce synthesis of cytochrome $d$ in cells grown at $35^{\circ} \mathrm{C}$ by imposing severe oxygen limitation have failed (M. V. Jones, unpublished data). The synthesis of this cytochrome may therefore respond to both oxygen tension and temperature.

That cytochrome $d$ functions as an alternative terminal oxidase in B. coagulans is indicated by the increased cyanide insensitive NADH oxidation. Cytochrome $d$ has been shown to have low cyanide sensitivity in other bacteria (Pudek \& Bragg, 1974; Knowles, 1976). It does not appear to have any particular role in the thermostability of the respiratory system as NADH oxidase from cells with or without detectable cytochrome $d$ was equally thermostable. This result is again an exception to the hypothesis that facultative thermophiles do not synthesize inherently thermostable proteins at mesophilic growth temperatures (Crabb et al., 1975, Heinen \& Lauwers, 1983).

Despite changes in cytochrome composition at different growth temperatures there was little difference in the azide sensitivity of NADH oxidation. Concentrations of azide sufficient to completely inhibit growth had little or no effect on respiration. The finding that anaerobic growth at mesophilic temperatures was equally sensitive to azide as aerobic growth indicated that azide was probably affecting a central metabolic activity. There was no evidence for a change in metabolic capability as seen in B. stearothermophilus (Jung et al., 1974) and anaerobic growth was equally efficient (as measured by cell yields) at both mesophilic and thermophilic temperatures.

Both mitochondrial and bacterial ATPases are known to be sensitive to azide (Linnett \& Beechley, 1979) and the inhibitor will bind to the soluble $\left(\mathrm{BF}_{1}\right)$ portion of the enzyme (Munoz et al., 1969; Yoshida et al., 1977). Concentrations of $0.1 \mathrm{mM}$-azide gave over $50 \%$ inhibition of ATPase from E. coli (Evans, 1969) and Micrococcus lysodeikticus (Munoz et al., 1969). We found the ATPase of B. coagulans to be slightly less sensitive to azide at $37^{\circ} \mathrm{C}$. However, the degree of inhibition depended on both the assay and the growth temperature. The ATPase in cell-free extracts prepared from cells grown and assayed at $55^{\circ} \mathrm{C}$ was substantially more resistant to azide than ATPase from $37^{\circ} \mathrm{C}$-grown cultures. The progressive decrease in azide inhibition with increased temperature reflects the pattern of growth in azide-containing broth. We propose that a major factor in the temperature-dependent azide sensitivity of $B$. coagulans is a modification of the ATPase with growth temperature.

Temperature-dependent changes in ATPase activity could occur through modifications in membrane-lipids as has been shown for several membrane-bound enzymes (Welker, 1976; De Kruyff et al., 1973). Alternatively, as azide can interact with the soluble portion of the ATPase molecule, a change in the subunit structure of the $\mathrm{BF}_{1}$ might be possible. It has been shown that in the obligatory thermophilic bacterium PS3 the $\gamma$ subunit was necessary for activity at high temperatures. In the absence of the $\gamma$ subunit the reconstituted enzyme was thermolabile and insensitive to azide (Yoshida et al., 1977). Studies with the ATPase of the facultative thermophile, $B$. coagulans, will provide an interesting comparison with this work and further information on the mechanisms of thermophily.

\section{REFERENCES}

Alberty, R. A. (1968). The effect of $\mathrm{pH}$ and metal ion concentration on the equilibrium hydrolysis of adenosine triphosphate to adenosine diphosphate. Journal of Biological Chemistry 243, 253-260.
AmelunXen, R. E. \& Murdock, A. L. (1978). Mechanisms of thermophily. CRC Critical Reriens in Microbiology 6, 343-393.

Castor, L. \& Chance, B. (1959). Photochemical 
determination of the oxidases of bacteria. Journal of Biological Chemistry 234, 1587-1592.

Crabb, J. W., Murdock, A. L. \& Amelunxen, R. E. (1975). A proposed mechanism of thermophily in facultative thermophiles. Biochemical and Biophysical Research Communications 62, 627-633.

De KruYfF, B., Van Duck, P. W. M., Goldbach, R. W., Demel, R. A. \& Van Deenen, L. L. M. (1973). Influence of fatty acid and sterol composition on the lipid phase transition and activity of membrane bound enzymes in Acholeplasma laidlawii. Biochimica et biophysica acta 330, 269-282.

Edwards, C. \& Jones, M. V. (1983). Production of a thermostable ATPase by the facultative thermophile, Bacillus coagulans. Archives of Microbiology 135, 74-76.

Edwards, C., Spode, J. A. \& Jones, C. W. (1978). The properties of adenosine triphosphatase from exponential and synchronous cultures of Alcaligenes eutrophus H16. Biochemical Journal 172, 253-260.

Evans, D. J. (1969). Membrane adenosine triphosphatase of Escherichia coli: activation by calcium ions and inhibition by monovalent cations. Journal of Bacteriology 100, 914-922.

Farrell, J. \& CAMPBell, L. L. (1969). Thermophilic bacteria and bacteriophages. Adtances in Microbial Physiology 3, 83-109.

Gibson, T. \& GordON, R. E. (1974). Bacillus. In Bergey's Manual of Determinatice Bacteriology, pp 529-550. Edited by R. E. Buchanan \& N. E. Gibbons. Baltimore: Williams \& Wilkins.

Gordon, R. E., Haynes, W. C. \& Pang, N. C. (1973). The genus Bacillus. United States Department of Agriculture Handbook no. 427.

Heinen, W. \& Lauwers, A. M. (1983). Changes in enzyme stability and fatty acid composition of Streptomyces sp., a facultative thermophilic Actinomycete. Archices of Microbiology 134, 247-250.

Jung, L., Jost, R., Stoll, E. \& Zuber, H. (1974). Metabolic differences in Bacillus stearothermophilus grown at $55^{\circ} \mathrm{C}$ and $37^{\circ} \mathrm{C}$. Archices of Microbiology 95. $125-138$.

KNowles, C. J. (1976). Microorganisms and cyanide. Bacteriological Reviews 40, 652-680.
LinNett, P. E. \& BeECHLEY, R. B. (1979). Inhibitors of the ATP synthetase system. Methods in Enzymology LV, 472-515.

McArthur, H. A. I. \& Reynolds, P. E. (1979). Peptidoglycan carboxypeptidase and endopeptidase activities of Bacillus coagulans NCIB 9365. Journal of General Microbiology 111, 327-355.

Munoz, E., Salton, M. R. J., NG, M. H. \& Schor, M. T. (1969). Membrane ATPase of Micrococcus lysodeikticus: Purification and properties of the soluble enzyme and properties of the membrane-bound enzyme. European Journal of Biochemistry 7, 490501 .

Novitsky, T. J., Chan, M., Himes, R. H. \& Akagi, J. M. (1974). Effect of temperature on growth and cell wall chemistry of a facultative thermophilic Bacillus. Journal of Bacteriology 117, 858-865.

Pudek, M. R. \& BRAGG, P. D. (1974). Inhibition by cyanide of the respiratory chain oxidases of Escherichia coli. Archives of Biochemistry and Biophysics 164, 682-693.

Rice, C. W. \& Hempfling, W. P. (1978). Oxygenlimited continuous culture and respiratory energy conservation in Escherichia coli. Journal of Bacteriology 134, 115-124.

Smith, L. (1978). Bacterial cytochromes and their spectral characteristics. Methods in Enzymology LIII, 202-212.

WELKER, N. E. (1976). Effect of temperature on membrane proteins. In Extreme Entironments: Mechanisms of Microbial Adaptation, pp. 229-254. Edited by M. R. Heinrich. New York: Academic Press.

West, I. C. \& Mitchell, P. (1974). The protontranslocating ATPase of Escherichia coli. FEBS Letters 40, 1-4.

Williams, R. A. D. (1975). Caldoactive and thermophilic bacteria and their thermostable proteins. Science Progress 62, 373-393.

Yoshida, M., Sone, N., Hirata, H. \& Kagawa, Y. (1977). Reconstitution of adenosine triphosphatase of thermophilic bacterium from purified individual subunits. Journal of Biological Chemistry 252, 3480 3485 . 